\title{
'Immigrant' forage kochia seed viability as impacted by storage methods
}

\author{
ALISON STEWART, VAL JO ANDERSON, AND STANLEY G. KITCHEN
}

Authors are adjunct faculty, Life Science Department, Palomar College, San Marcos, Calif. 92069; professor, Botany and Range Science Department, Brigham Young University, Provo, Ut. 84602; and botanist, Shrub Sciences Laboratory, Rocky Mountain Research Station, USDA Forest Service, Provo, Ut. 84606.

\begin{abstract}
'Immigrant' forage kochia (Kochia prostrata (L.) Schrad.) is a valuable introduced subshrub, often used in reclamation plantings and seedings on western rangelands. Seedling establishment is best from fresh seed; however, many users plant stored seed and experience poor seeding success. One cause for failure is loss of seed viability in storage. Forage kochia seed was harvested on 4 dates in fall 1996 from 2 sites (wildland and irrigated) and tested for viability when fresh and after storage treatments. Storage treatments included low and high seed water contents $(2-6 \%$ and $12-16 \%)$, cold and warm storage temperatures $\left(2^{\circ}\right.$ and $\left.25^{\circ} \mathrm{C}\right)$, and duration of storage $(4,8$, and 12 months). Mature, highly viable forage kochia seed remains viable in storage longer than seed harvested prematurely. Low seed water content $(2-6 \%)$ is essential to preserving maximum seed viability. Storing seed at a cold temperature $\left(2^{\circ} \mathrm{C}\right)$ is also helpful in maintaining viability.
\end{abstract}

Key Words: Kochia prostrata, revegetation, seed care, greenstripping

Forage kochia (Kochia prostrata (1.) Schrad.) was first introduced to the United States from the Soviet Union during the early 1960's (Keller and Bleak 1974). It is a semi-evergreen subshrub native to arid and semiarid regions of central Eurasia where it is valuable forage (Balyan 1972). Many assessions of forage kochia have been tested as possible forage and reclamation plants for semi-arid locations since its introduction (Keller and Bleak 1974, Stevens et al. 1985, McArthur et al. 1996). The variety 'Immigrant' was released in 1985 for forage and erosion control on greasewood-shadscale (Sarcobatus vermiculatus (Hook.) Torr. -Atriplex confertifolia ( Torr. \& Frem.) Wats.), sagebrush-grass (Artemisia spp.-grass), and pinyon-juniper (Pinus spp.-Juniperus spp.) rangelands of the Intermountain West (Stevens et al. 1985). Immigrant forage kochia has been used successfully as a revegetation species on harsh sites (Blauer et al. 1993, Frischknecht and Ferguson 1984, McArthur et al. 1974, Monsen and Turnipseed 1990) and is used extensively for seeding after fires on cheatgrass (Bromus tectorum (L.) dominated rangelands (Horton et al. 1994, McArthur et al. 1990). It has the valuable characteristic of sprouting after fires on these sites (McArthur et al. 1990).

Seed demand for Immigrant is generally high because of its range of uses and adaptability. For best establishment, fresh seed should be planted in late fall or early winter (Haferkamp et al. 1990, Monsen and Kitchen 1994). Many users, however, have

Manuscript accepted 10 Oct. 00.

\section{Resumen}

La Kochia forrajera (Kochia postrata (L) Schrad) 'Inmigrant' es un valioso subarbusto introducido que a menudo es utilizado en plantaciones y siembras para restaurar los pastizales del oeste. El establecimiento de plántulas es mejor a partir de semilla nueva, sin embargo, muchos usuarios plantan semilla almacenada y obtienen un pobre establecimiento de plántulas. Una de las causas del fracaso es la perdida de viabilidad de la semilla durante el almacenaje. Se cosecho semilla de Kochia forrajera en 4 fechas de otoño de 1996 y en 2 sitios (con riego y natural) y se probaron para determinar su viabilidad cuando estaban recién cosechadas y después de tratamientos de almacenamiento. Los tratamientos de almacenamiento incluyeron bajos $y$ altos contenidos de agua de la semilla (2-6\% y 12-16\%), temperaturas de almacenamiento frías y calientes $\left(2^{\circ}\right.$ y $\left.25^{\circ} \mathrm{C}\right)$ y duración de almacenamiento (4, 8 y 12 meses). La semilla madura de alta viabilidad permanece viable mas tiempo bajo almacenamiento que la semilla cosechada prematuramente. Un bajo contenido de agua (2-6\%) en la semilla es esencial para conservar la máxima viabilidad de la semilla. Almacenado la semilla a temperaturas frías $\left(2^{\circ} \mathrm{C}\right)$ también es útil para mantener la viabilidad.

planted year-old seed and experienced low seeding success. A probable cause of this problem is low seed viability due to short shelf-life of the seed between the time of viability testing and the time of purchase, which creates the potential for undetected losses in viability (Moghaddam 1978, Stevens and Jorgensen 1994). To maximize seeding success and financial return, it is beneficial to understand how viability changes over time in response to storage conditions (Stevens and Jorgensen 1994).

This research examined the effects of storage conditions, harvest date (an index of seed maturity), and maternal growth environment on viability of Immigrant forage kochia seed. These factors undoubtedly influence seeding success on western rangelands.

\section{Methods}

Fruits (hereafter referred to as seed) were collected from 2 sites. The first was a USDI Bureau of Land Management seeded (Immigrant) site, located $11 \mathrm{~km}$ north of Dugway, Tooele County, Ut. ( $40^{\circ} 20^{\prime} \mathrm{N} ., 112^{\circ} 44^{\prime} 36^{\prime \prime} \mathrm{W}$.) where several hundred mature forage kochia plants were present. The Natural Resources Conservation Service has classified the soil as a very deep, welldrained Tooele fine, sandy loam (Coarse-loamy, mixed, superac- 
tive, calcareous, mesic Typic Torriorthent) which receives an average of $17 \mathrm{~cm}$ of annual precipitation (Trickler, et al. 2000). The second site was an irrigated field operated by Stevenson Intermountain Seed near Manti, Sanpete County, Ut. (39 $19^{\circ} 30^{\prime \prime}$ N., $111^{\circ} 38^{\prime} 8^{\prime \prime}$ W.) where certified Immigrant forage kochia seed is grown for commercial use. The crop is irrigated as needed to maximize production, and the soil is a Sigurd gravely loam (Loamy-skeletal, carbonatic, mesic Xeric Torrifluvent) (Soil Conservation Service 1981).

Seed was harvested from both sites in 1996 on 4 October, 18 October, 1 November, and 15 November. Twenty plants were selected at each site to represent the population's variability. Seed was handstripped from each of these plants on each collection date and the phenological stage of seed maturity was recorded to allow application of this data to subsequent years and multiple sites. The seeds were then air-dried for 3 to 10 days. Empty and immature fruits, fruit fragments, leaves, and small stems were removed using $1.0 \mathrm{~mm}, 1.8 \mathrm{~mm}$, and $4.8 \mathrm{~mm}$ rounds (Seedburo Equipment Company, Chicago, Ill.)

A subsample (3 to $20 \mathrm{~g}$ ) of each seed lot was dried to $0 \%$ moisture in a drying oven at $125^{\circ} \mathrm{C}$. This sublot was used as a reference in calculating seed water content for the levels desired in storage. The remaining fresh seed was then divided evenly into 32 sublots for a complete factorial arrangement of the storage treatments [4 harvest dates $\times 2$ growth environments (wildland and irrigated sites) x 3 storage temperatures (fresh seed with no storage, cold storage at $2^{\circ} \mathrm{C}$, and warm storage at $\left.25^{\circ} \mathrm{C}\right) \times 3$ levels of seed water contents during storage (fresh seed with no storage, low seed water content at 2-6\%, and high seed water content at $12-16 \%) \times 4$ storage lengths $(0,4,8$, and 12 months $)]$. Seed was then further air-dried or rehydrated until the desired seed water content levels were achieved. Each of the sublots was weighed and stored in a plastic vial, with each group of vials sealed in a plastic bag and placed in a cardboard box.

Percent seed viability was assessed for each seed lot, when fresh and after each storage period. Each test included 4 replications of 25 seeds from each seedlot. Seed was placed in $100 \mathrm{~mm} \mathrm{X} 15 \mathrm{~mm}$ plastic petri dishes on two 1-mm thick blotters (Anchor Paper, St. Paul, Minn.) saturated with tap water. Dishes were randomized, stacked, and placed in plastic bags in order to retain moisture. To ensure even light treatment for all dishes, a blank dish with 2 dampened blotters was placed on the top of each stack. Blotters were resaturated as needed throughout the germination test. Stacks were randomly arranged in a germination chamber and rearranged after weekly counts.

Seed was incubated in a controlled environment chamber with a 12-hour diurnal photoperiod at $10 / 20^{\circ} \mathrm{C}$. Every 7 days, the germinated seed in each dish were counted and removed. Germination was defined as $5+\mathrm{mm}$ radicle emergence (Young et al. 1981). After 28 days, firmness of ungerminated seed in each dish was determined using a cut test to examine embryonic tissue (Association of Official Seed Analysts 1988). Dormant seed was defined as firm but ungerminated after 28 days.
Germinated seed plus dormant seed equaled total viable seed for each dish.

Percent viability was calculated for each replication and was arcsin transformed before analysis to normalize the data. A factorial analysis of variance appropriate to the completely randomized experimental design was used to determine significance of treatments and interactions (SAS 1998).

\section{Results and Discussion}

\section{Maternal Growth Environment}

Maternal growth environment of the seed may affect ripening rate or other factors of importance to seed quality (Balyan 1972). Effects of seed maturity, growth environment, and storage conditions on seed viability of Immigrant forage kochia seed were highly significant $(\mathrm{p}<0.01)$. Seed from the wildland site was more viable $(75 \%)$ when fresh compared to seed from the irrigated site $(65 \%)$. Viability after storage was lower for seed from both sites, with the relative difference being similar to that of their original viability, as wildland seed was $45 \%$ and irrigated seed was $38 \%$ viable overall, after 12 -months storage. Causes of these differences would be highly speculative at this point, as further studies over time or involving more sites would be warranted. Thus, in all following discussion, tables, and figures, data shown are means from both sites.

\section{Harvest Date}

An important consideration concerning low seed viability of forage kochia is early harvest. Seed growers may feel compelled

Table 1. Means (standard errors) of percent viability for 'Immigrant' forage kochia seed incubated for 28 days in a 12-hour diurnal photoperiod at $10 / 20^{\circ} \mathrm{C}$. Seed was harvested from an irrigated site and a wildland site in central Utah in fall 1996 and tested for viability when fresh and after storage treatments. High seed water content was $12-16 \%$ and low was $2-6 \%$. Storage at a cold temperature was $2^{\circ} \mathrm{C}$, and the warm temperature was $25^{\circ}$ C. For all means, $\mathbf{N}=8$.

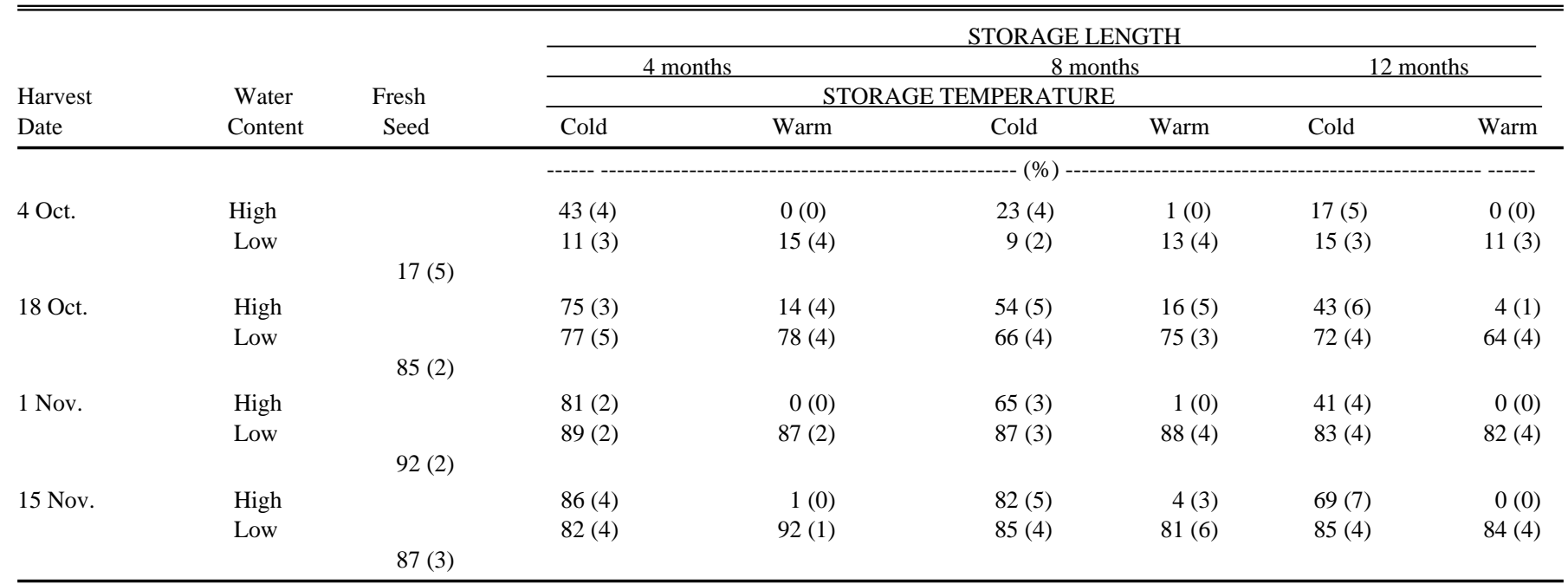




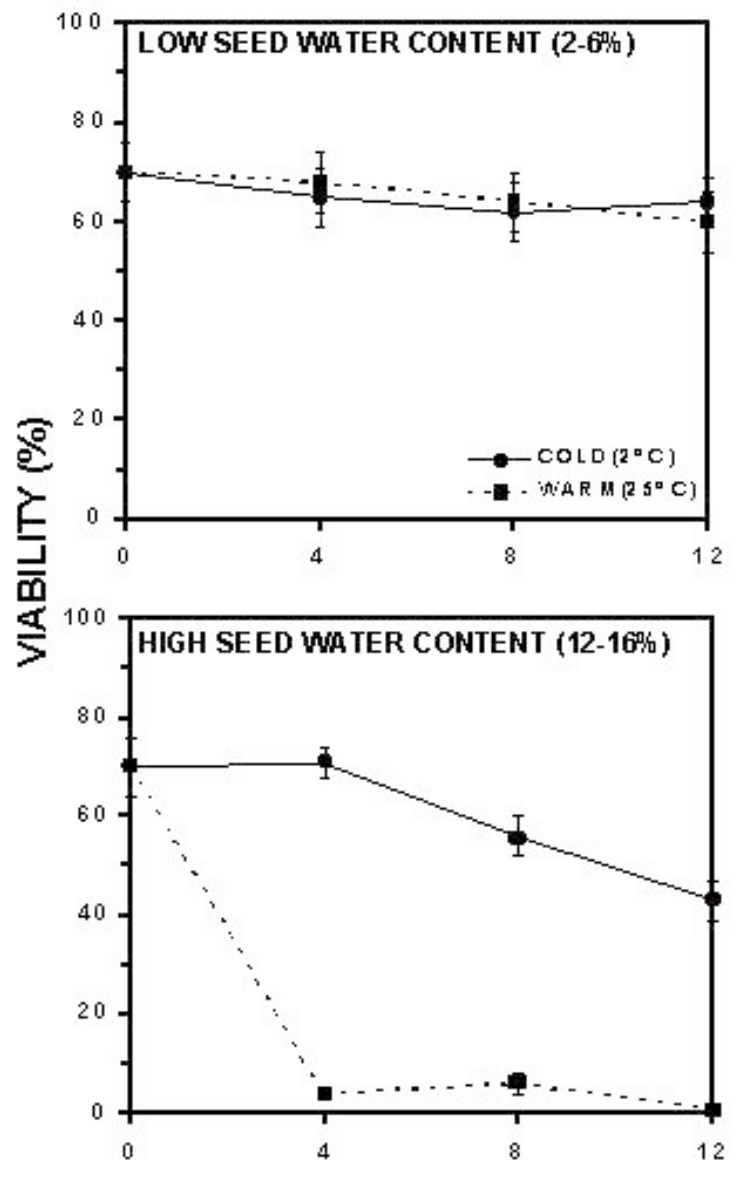

LENGTH OF STORAGE (MONTHS)

Fig. 1. Percent viability of 'Immigrant' forage kochia seed from all collection dates and both growth environments stored with 2 seed water content levels (low at $2-6 \%$ and high at $12-16 \%$ ) and at 2 temperatures (cold at $2^{\circ} \mathrm{C}$ and warm at $25^{\circ} \mathrm{C}$ ) shown over increasing length of storage $(0,4,8$, and 12 months). This 3-way interaction was significant at $p<0.01$. For all means $N=32$.
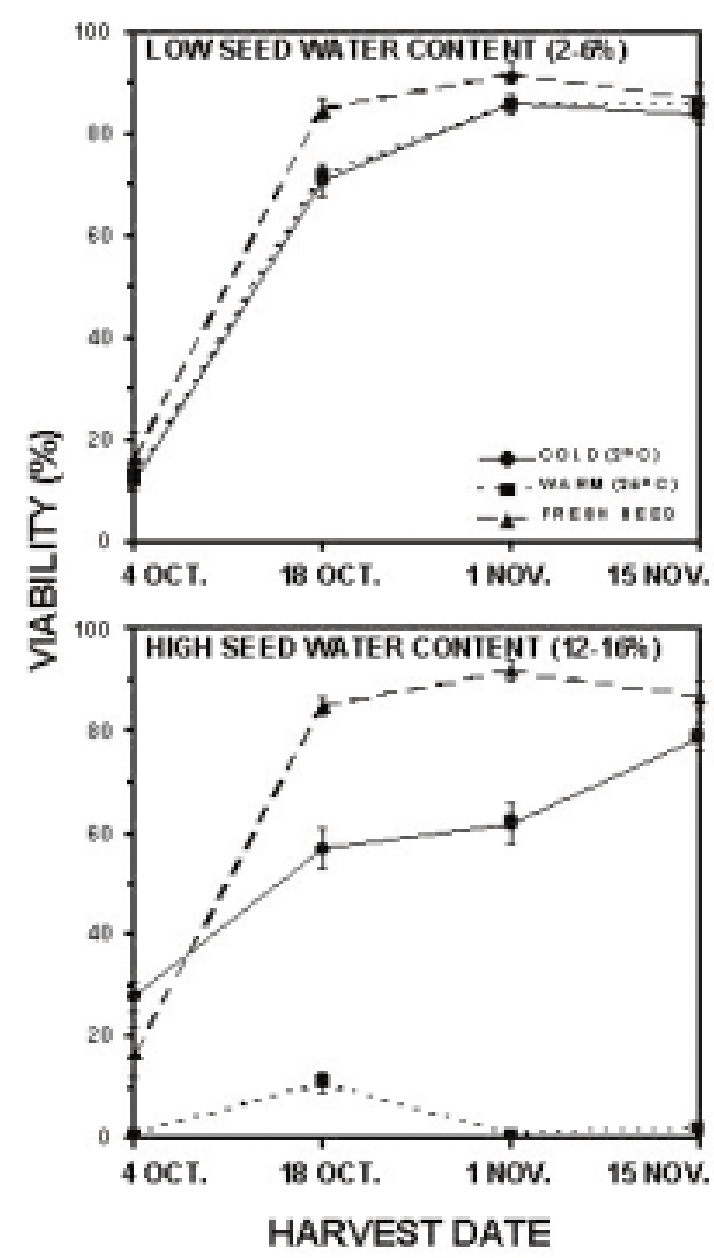

Fig. 2. Percent viability of 'Immigrant' forage kochia seed from both growth environments, meaned across all storage lengths, stored with 2 seed water content levels (low at 2-6\% and high at 12-16\%) and at 2 temperatures (cold at $2^{\circ} \mathrm{C}$ and warm at $25^{\circ} \mathrm{C}$ ) shown over successive harvest dates $(4 \mathrm{October}$, 18 October, 1 November, and 15 November). This 3-way interaction was significant at $p<0.01$. For means of fresh seed $N=8$, and for all other means $N$ $=24$. to harvest before the seed ripens fully in October or November to prevent losses associated with fall storms (Moghaddam 1978). However, immature seed may not be capable of surviving storage and/or producing viable seedlings (Waller et al. 1983).

Seed collected from both sites on the first harvest date (4 October) were immature. The seed and stems were still very green, moist, and not easily stripped from the inflorescence. Seed maturity, or the developmental stage for optimum germination, is judged in the field stage when seed can be easily stripped by hand from the inflorescences, after the stems have changed to a reddish color and dry up (Balyan 1972, Waller et al. 1983). By 18 October, approximately half of the seed at the collection sites had started to mature and turn red. By 1 November, the seed was fully ripe, as it was very red, dry, and easily hand-stripped. By the fourth harvest, seed at the wildland site was still very ripe and mostly still on the stalk. At the commercial site, large amounts of seed had already shattered and dropped, signifying it had reached full maturity.

When fresh seed was tested, viability was low $(17 \%)$ for seed from the first harvest, as expected from its appearance. Viability was high for fresh seed from the second, third, and fourth harvests ( $88 \%$ collectively) because all or most of the seed was mature by then. Seed from the last 3 harvests also retained viability over time (Table 1 ). Seed viability from the first harvest varied but was typically lower with storage.

\section{Storage Conditions}

Forage kochia seed is known to have a short shelf-life, especially under uncon- trolled warehouse storage conditions (Balyan 1972, Jorgensen and Davis 1984, Keller and Bleak 1974). Not stored properly, seed can lose 80 to $90 \%$ viability in less than a year (Moghaddam 1978, Stevens et al. 1985).

The interaction among seed water content, storage temperature, and length of storage was highly significant $(\mathrm{p}<0.01)$. Figure 1 illustrates the effects of seed water content and storage temperature over time on seed viability. Seed stored with a high seed water content at a warm temperature lost $94 \%$ viability, while seed stored at a cold temperature with a high seed water content lost only $20 \%$ viability. Storing seed with low water content, whether in a cold or warm storage temperature, preserved seed viability for the majority of seed, with only $9 \%$ viability lost overall. It is imperative to store forage 
kochia seed with a low water content to ensure preservation of viability.

Differences among the effects of seed water content, storage temperature, and seed maturity level also led to a highly significant interaction $(p<0.01)$. Seed stored with low water content at a cold or warm temperature was able to retain most of the seed viability after storage (Fig. 2). This was especially true for the most mature seed from the latest harvest. They remained $85 \%$ viable after 12 months in storage, compared to $87 \%$ viable when fresh. Mature seed appeared to be most resilient to adverse storage conditions. Figure 2 also depicts the dramatic loss of viability in seed from all harvest dates which were stored with a high seed water content at a warm temperature. Seed stored with a high seed water content in a cold temperature retained much more viability than those stored with the same seed water content at a warm temperature. Storing forage kochia seed at a cold temperature aids in retaining seed viability; however, storage with a low seed water content is most effective. Stewart et al. (1999) found that these storage conditions also preserved maximum dormancy and maintained the most delayed and desynchronized germination rate for forage kochia seed.

\section{Conclusions}

Recommendations to obtain higher seed viability from stored Immigrant forage kochia seed include delaying harvest until seed is mature, when seed is red and easily hand-stripped from the inflorescence. This is typically sometime from October to November (Balyan 1972). Early collection yields mostly nonviable seed, while later collection yields highly viable seed which are also longer-lived in storage.

To maintain high seed viability in storage, first priority should be given to drying fresh seed to a low seed water content (2-6\%) and maintaining that level through the term of storage. A second priority should be to store the low-water content seed at a cold temperature $\left(2^{\circ} \mathrm{C}\right)$. As the use of forage kochia increases on western rangelands, these recommendations will aid in obtaining and maintaining the highest possible viability when Immigrant forage kochia seed is stored and planted.

\section{Literature Cited}

Association of Official Seed Analysts. 1988. Rules for testing seeds. Stone Printing Company, Lansing, Mich. Vol. 6, No. 2.

Balyan, G. A. 1972. Prostrate summer cypress and its culture in Kirghizia. (Translated from Russian) Al Ahram Cen. Science. Transl., Nat. Tech. Information Ser. TT77-59026.

Blauer, A. C., E. D. McArthur, R. Stevens, and S. D. Nelson. 1993. Evaluation of roadside stabilization and beautification plantings in south-central Utah. USDA Forest Serv. Res. Paper INT-462. Ogden, Ut.

Frischknecht, N. C. and R. B. Ferguson. 1984. Performance of Chenopodiaceae species on processed oil shale, p. 293-297. In: A. R. Tiedemann, E. D. McArthur, H. C. Stutz, R. Stevens, and K. L. Johnson (compilers). Proc. symposium on the biology of Atriplex and related chenopods. USDA Forest Serv. Gen. Tech. Report INT-172. Odgen, Ut.

Haferkamp, M. R., D. C. Ganskopp, K. L. Marietta, and B. W. Knapp. 1990. Environmental influences on germination of utricles and seedling establishment of 'Immigrant' forage kochia. J. Range Manage. 23:518-522

Horton, H. H., S. B. Monsen, R. L. Newhall, and R. Stevens. 1994. Forage kochia holds ground against cheatgrass, erosion. Utah Sci. 55:10-11.

Jorgensen, K. R. and J. N. Davis. 1984. A technique for retaining seed viability in Kochia prostrata (L.) Schrad. p. 166-167. In: A. R. Tiedemann, E. D. McArthur, H. C. Stutz, R. Stevens, and K. L. Johnson (compilers). Proc. symposium on the biology of Atriplex and related chenopods. USDA Forest Serv. Gen. Tech. Report INT-172. Odgen, Ut.

Keller, W. and A. T. Bleak. 1974. Kochia prostrata: a shrub for western ranges?. Utah Sci. 35:24-25.

McArthur, E. D., B. C. Guinta, and A. P. Plummer. 1974. Shrubs for restoration of depleted ranges and disturbed areas. Utah Sci. 34:28-33.

McArthur, E. D., A. C. Blauer, and R. Stevens. 1990. Forage kochia competition with cheatgrass in central Utah. p. 56-65. In: E. D. McArthur, E. M. Romney, S. D. Smith, and P. T. Tueller (compilers). Proc. symposium on cheatgrass invasion, shrub dieoff, and other aspects of shrub biology and management. USDA Forest Serv. Gen. Tech. Report INT-276. Odgen, Ut.

McArthur, E. D., S. C. Sanderson, and J. N. Davis. 1996. Adaptation of forage kochia accessions across an environmental gradient in Rush Valley, Utah. Arid Soil Research and Rehabilitation 10:125-138.

Moghaddam, M. R. 1978. Kochia prostrataa plant material for range improvement in arid and semiarid regions. Rangeman's J. 5:153-154.

Monsen, S. B. and S. G. Kitchen. 1994. Annual Report—summary report of progress related to Interagency Agreement No. ID910 between USDI, Idaho Bureau of Land Management and USDA, Forest Service, Intermoun. Res. Sta. USDA, Forest Serv., Intermoun. Res. Sta., Shrub Sci. Lab., Provo, Ut.

Monsen, S. B. and D. Turnipseed. 1990. Seeding forage kochia into cheatgrass infested areas. p. 66-71. In: E. D. McArthur, E. M. Romney, S. D. Smith, and P. T. Tueller (compilers). Proc. symposium on cheatgrass invasion, shrub dieoff, and other aspects of shrub biology and management. USDA Forest Serv. Gen. Tech. Rep. INT-276. Odgen, Ut.

SAS. 1998. SAS user's guide. SAS Institute, Cary, N. C.

Soil Conservation Service. 1981. Soil survey of Sanpete Valley Area, Utah. USDA, Soil Cons. Serv., Washington, D. C.

Stevens, R. and K. R. Jorgensen. 1994. Rangeland species germination through 25 and up to 40 years of warehouse storage. p. 257-265. In: S. B. Monsen and S. G. Kitchen (compilers). Proc. ecology and management of annual rangelands. USDA Forest Serv. Gen. Tech. Report INT-GTR-313. Ogden, Ut.

Stevens R., K. R. Jorgensen, E. D. McArthur, and J. N. Davis. 1985. 'Immigrant' forage kochia. Rangelands 7:22-23.

Stewart, A., V. J. Anderson, and S. G. Kitchen. 1999. 'Immigrant' forage kochia (Kochia prostrata) seed germination as affected by storage conditions. p. 274-279. In: E. D. McArthur, W. K. Ostler, C. L. Wambolt (compilers). Proc. shrubland ecotones. USDA Forest Serv., Rocky Mountain Res. Station Proc. RMRS-P-11. Ogden, Ut.

Trickler, D., C. D. Franks, and D. Hall. 2000. Soil survey of Tooele County, Utah, Parts of Box Elder County, Utah, Davis County, Utah, Millard County, Utah, Salt Lake County, Utah, White Pine County, Nevada. USDA Nat. Resources Conserv. Serv. Washington, D. C.

Waller, S. S., C. M. Britton, D. K. Schmidt, J. Stubbendieck, and F. A. Sneva. 1983. Germination characteristics of two varieties of Kochia prostrata (L.) Schrad. J. Range Manage. 36:242-245.

Young, J. A., R. A. Evans, R. Stevens, and R. L. Everett. 1981. Germination of Kochia prostrata seed. Agron. J. 73:957-961. 